Article

\title{
Isolation and Synthesis of a Bioactive Benzenoid Derivative from the Fruiting Bodies of Antrodia camphorata
}

\author{
Pi-Yu Chen ${ }^{1, \dagger}$, Jen-Der Wu ${ }^{1}$, Kai-Yih Tang ${ }^{2, \dagger}$, Chieh-Chou Yu ${ }^{3}$, Yueh-Hsiung Kuo ${ }^{4}$, \\ Wen-Bin Zhong ${ }^{5, *}$ and Ching-Kuo Lee ${ }^{1, *}$
}

1 School of Pharmacy, Taipei Medical University, Taipei 110, Taiwan; E-Mails: e023089103@tmu.edu.tw (P.-Y.C.); jd0331@tmu.edu.tw (J.-D.W.)

2 Yong Chung Prosperous Biotech Co. Ltd., New Taipei 231, Taiwan; E-Mail: xz029465@gmail.com

3 Twherb Biomedical Co. Ltd., Jhubei 302, Taiwan; E-Mail: 123@twherb.com.tw

4 Tsuzuki Institute for Traditional Medicine, College of Pharmacy, China Medical University, 404 Taichung, Taiwan; E-Mail: yhkuo@ntu.edu.tw

5 School of Medicine, Taipei Medical University, Taipei 110, Taiwan

$\dagger$ These authors contributed equally to this work.

* Authors to whom correspondence should be addressed; E-Mails: wbzong@tmu.edu.tw (W.-B.Z.); cklee@tmu.edu.tw (C.-K.L.); Tel.: +886-2-27361661 (ext. 3183) (W.-B.Z.); Fax: +886-2-23772265 (C.-K.L.).

Received: 15 May 2013; in revised form: 20 June 2013 / Accepted: 21 June 2013 / Published: 28 June 2013

\begin{abstract}
A new enynyl-benzenoid, antrocamphin O (1,4,7-dimethoxy-5-methyl-6-(3'methylbut-3-en-1-ynyl)benzo[d][1,3]dioxide), and the known benzenoids antrocamphin A and 7-dimethoxy-5-methyl-1,3-benzodioxole, were isolated from the fruiting bodies of Antrodia camphorata (Taiwanofungus camphoratus). The structure of antrocamphin $\mathrm{O}$ was unambiguously assigned by the analysis of spectral data (including 1D and 2D NMR, high-resolution MS, IR, and UV) and total synthesis. Compound 1 was prepared through the Sonogashira reaction of 5-iodo-4,7-dimethoxy-6-methylbenzene and 2-methylbut-1-en-3-yne as the key step. The benzenoids were tested for cytotoxicity against the HT29, HTC15, DLD-1, and COLO 205 colon cancer cell lines, and activities are reported herein.
\end{abstract}

Keywords: Antrodia camphorata; enynyl-benzenoid; antrocamphin O; synthesis; cytotoxic activity 


\section{Introduction}

Antrodia camphorata (Taiwanofungus camphoratus), also known as "Niu-chang-chih," belongs to the family Polyporaceae in the Basidiomycetes. Designated an endangered species in Taiwan, the fungus is a rare and unique mushroom used in folk medicine and as a health food. To date, over 200 constituent compounds, consisting of small molecules (terpenoids, benzenoids, lignans, benzoquinone derivatives, and succinic and maleic derivatives) and macromolecules (polysaccharides, nucleic acids, and proteins), have been reported [1-3]. Preparations from the fruiting bodies have been used for the prevention or treatment of numerous maladies, including liver diseases, food and drug intoxication, diarrhea, abdominal pain, hypertension, itchy skin, and tumorigenic diseases [4]. Previous research has shown the anti-cancer and anti-inflammatory effects of the triterpenoids derived from A. camphorate [3,5]. The major chemical constituents, the enynyl-benzenoids, are the key components responsible for anti-inflammatory activity [6,7]. Because the growth rate of $A$. camphorata in both the wild and under cultivation is very slow, the fruiting bodies are rare and expensive. Therefore, synthesis of the active compounds is very important. In this paper, we isolated and elucidated the structure of a new active compound, the enynyl-benzenoid antrocamphin O (1), and the known benzenoids, antrocamphin A (2) [8] and 4,7-dimethoxy-5-methyl-1,3-benzodioxole (3) [9], from the fruiting bodies of A. camphorata. We also describe the total synthesis of $\mathbf{1}$. The benzenoids were tested for cytotoxicity against the HT29, HTC15, DLD-1, and COLO 205 colon cancer cell lines, and their activities are reported herein.

\section{Results and Discussion}

\subsection{Isolation and Identification}

The EtOH extract of the fruiting bodies of A. camphorata (48 g, dried) was subjected to liquid-liquid partitioning with EtOAc, $\mathrm{BuOH}$, and $\mathrm{H}_{2} \mathrm{O}$. The bioactive EtOAc-soluble fraction was chromatographed over silica gel, followed by HPLC separation using refractive index detection. This procedure afforded three compounds 1-3. The structural elucidation of compound 1 was carried out using spectroscopic analysis and 2D NMR techniques, including ${ }^{1} \mathrm{H}-{ }^{1} \mathrm{H}$ COSY, heteronuclear multiple quantum correlation (HMQC), and heteronuclear multiple bond correlation (HMBC) experiments. Compound 1 was obtained as a colorless amorphous powder. The molecular formula was established as $\mathrm{C}_{15} \mathrm{H}_{16} \mathrm{O}_{4}$ by high-resolution electron spray ionization MS (HRESIMS, $m / z 261.1123[\mathrm{M}+\mathrm{H}]^{+}$, calcd for $\mathrm{C}_{15} \mathrm{H}_{17} \mathrm{O}_{4}$, 261.1127). The UV spectrum of 1 displayed absorption maxima at 258 and $288 \mathrm{~nm}$, and the IR spectrum exhibited characteristic absorption peaks for alkynes $\left(2183 \mathrm{~cm}^{-1}\right)$ and alkenes $\left(1605 \mathrm{~cm}^{-1}\right)$. The ${ }^{1} \mathrm{H}-\mathrm{NMR}\left(\mathrm{CDCl}_{3}\right)$ data for $\mathbf{1}$ (Table 1) showed terminal methylene protons at $\delta 5.35(1 \mathrm{H}$, br s, H-4'a) and $\delta 5.24(1 \mathrm{H}$, br s, H-4'b), two methoxy protons at $\delta 3.85(3 \mathrm{H}, \mathrm{H}-3)$ and $3.96(3 \mathrm{H}, \mathrm{H}-6)$, and two methyl singlets at $\delta 2.25(3 \mathrm{H}, \mathrm{s}, 4-\mathrm{Me})$ and $\delta 1.98\left(3 \mathrm{H}\right.$, br s, H-5'). The ${ }^{13} \mathrm{C}-\mathrm{NMR}$ data for $\mathbf{1}$ (Table 1) indicated 15 carbon resonance signals, in agreement with the HRESIMS data, including olefinic peaks at $\delta 121.0\left(\mathrm{C}-4^{\prime}\right)$ and $\delta 127.2\left(\mathrm{C}-3^{\prime}\right)$, two methoxy groups at $\delta 60.0(3-\mathrm{OMe})$ and $\delta 60.3(6-\mathrm{OMe})$, two methyl groups at $\delta 13.8(4-\mathrm{Me})$ and $\delta 23.6\left(\mathrm{C}-5^{\prime}\right)$, an $\mathrm{sp}^{3}$ methylene at $\delta 101.4$, and other eight quaternary carbons $(83.5,97.5,109.9,127.8,136.3,137.2,139.5$, and 139.8). The structure of 1 was assigned by 2D NMR data (COSY, HSQC, and HMBC). A ${ }^{1} \mathrm{H}-{ }^{1} \mathrm{H}$ COSY correlation for $\mathrm{H}-5^{\prime} / \mathrm{H}-4^{\prime}$ and HMBC cross-peaks of $\mathrm{H}-5^{\prime}$ to $\mathrm{C}-2^{\prime}, \mathrm{C}-3^{\prime}$, and $\mathrm{C}-4^{\prime}$ suggested the presence of an enynyl moiety. 
From 3-OCH$\underline{H}_{3}(\delta 3.85)$ to $\mathrm{C}-3,4-\mathrm{C}_{3}(\delta 2.25)$ to $\mathrm{C}-3 / \mathrm{C}-4 / \mathrm{C}-5$, and $6-\mathrm{OCH}_{3}(\delta 3.96)$ to $\mathrm{C}-6$ by $\mathrm{HMBC}$ experiment, the chemical structure of 1 was identified to be as shown in Figure 1. This is the first report from natural sources of this compound, which was given the trivial name antrocamphin O.

Table 1. NMR Spectroscopic Data for 1 in $\mathrm{CDCl}_{3}(500 \mathrm{MHz})$.

\begin{tabular}{|c|c|c|c|}
\hline \multirow{2}{*}{ Position } & \multicolumn{3}{|c|}{ Antrocamphin O (1) } \\
\hline & $\boldsymbol{\delta}_{\mathrm{C}}$ & $\delta_{\mathrm{H}}(J$ in $\mathrm{Hz})$ & НМBC \\
\hline 1 & 136.3 & & \\
\hline 2 & 139.5 & & \\
\hline 3 & 137.2 & & \\
\hline 4 & 127.8 & & \\
\hline 5 & 109.9 & & \\
\hline 6 & 139.8 & & \\
\hline $1^{\prime}$ & 83.5 & & \\
\hline $2^{\prime}$ & 97.5 & & \\
\hline $3^{\prime}$ & 127.2 & & \\
\hline $4^{\prime}$ & 121.0 & $5.24(\mathrm{br} \mathrm{s}), 5.35(\mathrm{br} \mathrm{s})$ & $2^{\prime}, 3^{\prime}, 5^{\prime}$ \\
\hline $5^{\prime}$ & 23.6 & 1.98 (br s) & $2^{\prime}, 3^{\prime}, 4^{\prime}$ \\
\hline $6^{\prime}$ & 101.4 & $5.91(\mathrm{~s})$ & 1,2 \\
\hline 3-OMe & 60.0 & $3.85(\mathrm{~s})$ & 3 \\
\hline 6-OMe & 60.3 & $3.96(\mathrm{~s})$ & 6 \\
\hline 4-Me & 13.8 & $2.25(\mathrm{~s})$ & $3,4,5$ \\
\hline
\end{tabular}

Figure 1. Structures of 1-3 from the fruiting bodies of $A$. camphorate.

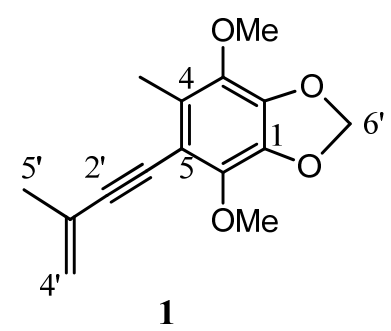

1

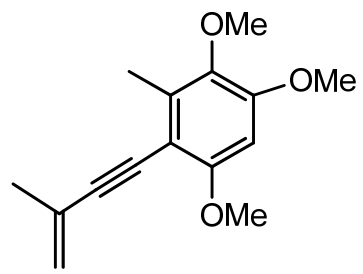

2<smiles>COc1cc(C)c(OC)c2c1OCO2</smiles>

3

\subsection{Synthesis and Structural Characterization of Antrocamphin O (1)}

To establish the proposed structure of 1 unambiguously, a sample of reference material was needed, and this prompted us to prepare the authentic compound. The reaction sequence outlined in Scheme 1 was followed. Treatment of the readily available 2,3,4,5-tetramethoxytoluene (4) with $\mathrm{AlCl}_{3}$ followed by demethylation afforded 5 and its isomers [10]. Purification of the isomeric mixture by column chromatography gave 5 in an overall yield of $34 \%$. The NMR data analysis $\left({ }^{1} \mathrm{H},{ }^{13} \mathrm{C}-\mathrm{NMR}\right.$, and nOe) revealed the exact structure of $\mathbf{5}$. After protection with bromochloromethane in the presence $\mathrm{Cs}_{2} \mathrm{CO}_{3}$ at $110{ }^{\circ} \mathrm{C}$ [11], the 1,3-benzodioxole $\mathbf{3}$ was obtained in $70 \%$ yield. Iodination of $\mathbf{3}$ with $N$-iodosuccinimide [12] produced 5-iodo-4,7-dimethoxy-6-methylbenzo[d][1,3]dioxole 6. The Sonogashira reaction [13] was utilized to couple iodide 6 with 2-methyl-1-buten-3-yne, using the catalysts $\mathrm{Pd}\left(\mathrm{PPh}_{3}\right)_{4}$ and $\mathrm{CuI}$. This key reaction led to the desired compound, antrocamphin $\mathrm{O}(\mathbf{1})$. 
Scheme 1. The synthetic route to compound 1.

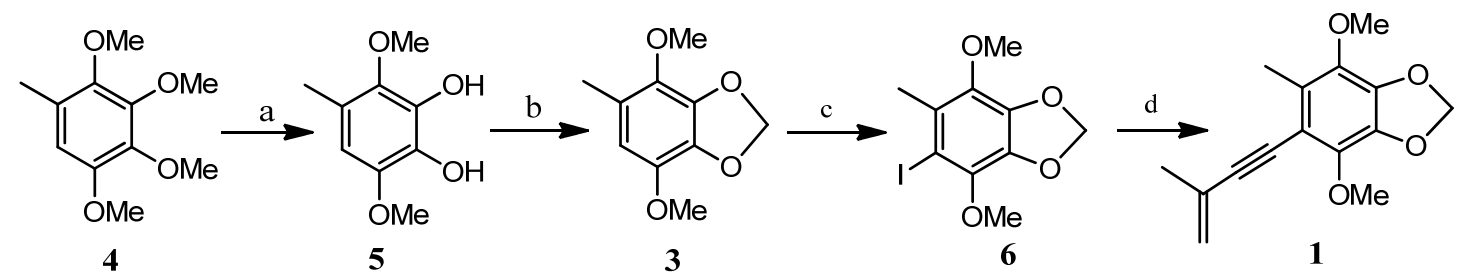

Reagents and conditions: a, $\mathrm{AlCl}_{3}, 40{ }^{\circ} \mathrm{C}, 34 \% ; \mathrm{b}, \mathrm{CH}_{2} \mathrm{ClBr}, \mathrm{Cs}_{2} \mathrm{CO}_{3}, 110{ }^{\circ} \mathrm{C}, 70 \% ; \mathrm{c}, N$-iodosuccinimide, $37{ }^{\circ} \mathrm{C}, 88 \%$; d, $\mathrm{Pd}\left(\mathrm{Ph}_{3}\right)_{4}, \mathrm{CuI}, \mathrm{Et}_{3} \mathrm{~N} / \mathrm{THF}, 90{ }^{\circ} \mathrm{C}, 16 \%$.

\subsection{Cytotoxicity Assay}

The cytotoxicity evaluation of compounds 1-3 against four human cancerous cell lines (HT29, HTC15, DLD-1, and COLO 205) showed that 1-3 were moderately or less active than 5-fluorouracil (5-FU), except against the COLO 205 cell line (Figure 2). Antrocamphin O (1) was a potent inhibitor of COLO 205 colon cancer, with higher activity than the reference compound 5-FU (Table 2).

Figure 2. Effects of AC1-derived compounds on cell survival inhibition. Colon cancer cells were either treated with compound $\mathbf{1}-\mathbf{3}$, or 5-FU for $48 \mathrm{~h}$. MTT test was used to exam the relative cell number. $\mathbf{1 - 3}$, and 5-FU concentration-dependently inhibited the cell viability in 4 clones of colon cancer cells. Values represent the means \pm S.E.M. $(n=3)$. Significance was accepted at $p<0.05$.

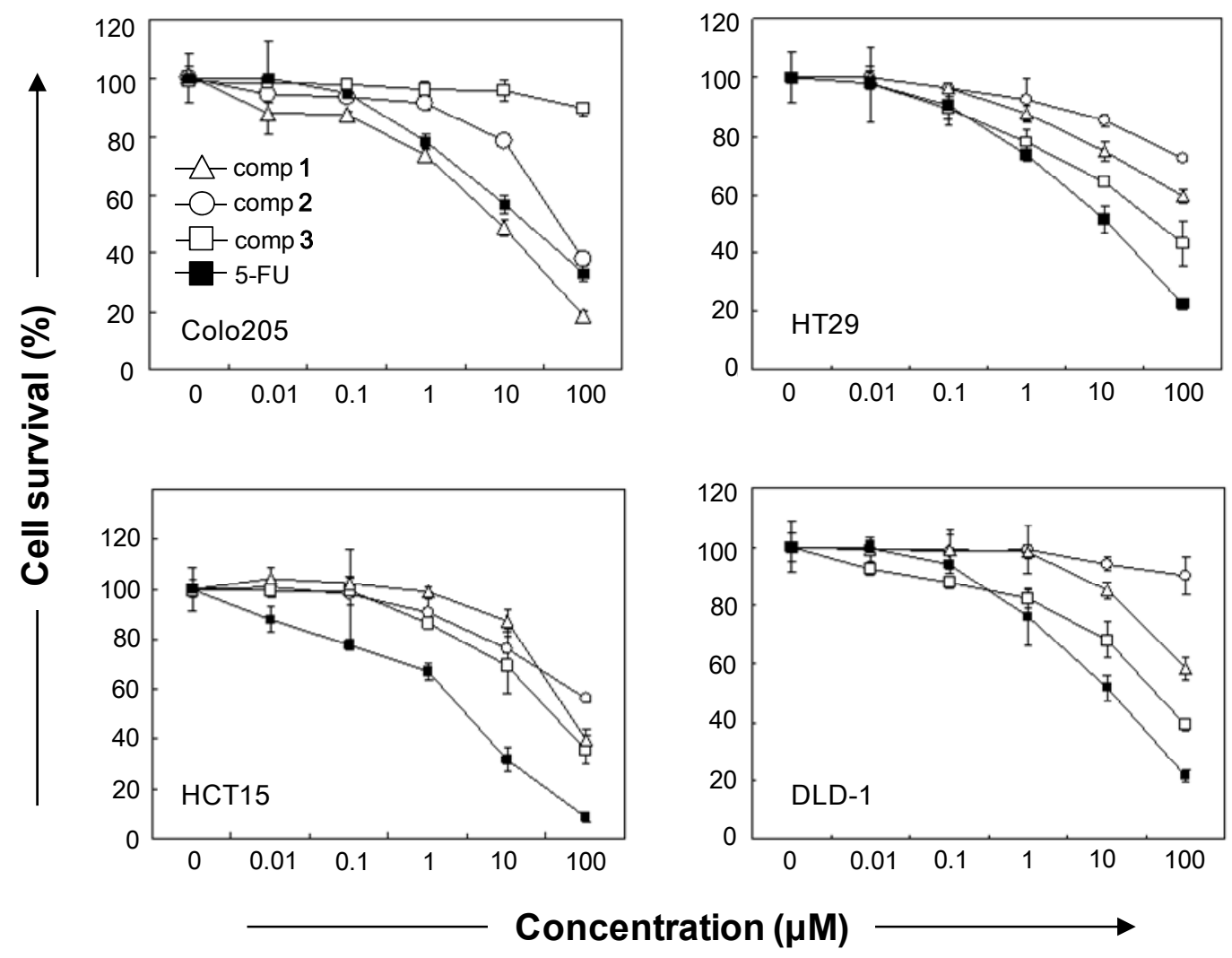


Table 2. The $\mathrm{IC}_{50}$ cytotoxicity of compounds 1-3 and 5-FU toward different colon cancer cells.

\begin{tabular}{ccccc}
\hline \multirow{2}{*}{ Compound } & \multicolumn{5}{c}{ IC $_{\mathbf{5 0}}(\boldsymbol{\mu M})$} \\
\cline { 2 - 5 } & HT29 & HTC15 & DLD-1 & Colo205 \\
\hline $\mathbf{1}$ & $>100$ & 70 & $>100$ & 9.3 \\
$\mathbf{2}$ & $>100$ & $>100$ & $>100$ & 43.4 \\
$\mathbf{3}$ & 14 & 39 & 40 & $>100$ \\
$\mathbf{5 - F U}$ & 11.2 & 3.1 & 9.5 & 17 \\
\hline
\end{tabular}

\section{Experimental}

\subsection{General Methods}

IR spectra were recorded on a JASCO 4100 FT-IR spectrometer. NMR data were recorded on a Bruker DRX-500 SB 500 MHz instrument (Bruker, Rheinstetten, Germany) with $\mathrm{CDCl}_{3}$ as solvent and TMS as internal standard. ESIMS and HRESIMS data were acquired using an ABI API 4000Q Trap and ABI XL Q-TOF mass spectrometer (Applied Biosystems, Foster City, CA, USA), respectively. Semi-preparative HPLC was performed on a Hitachi L-7110 HPLC with a refractive index detector (Thermo Separation Products, Sunnyvale, CA, USA). A Phenomenex Luna silica column (5 $\mu$, $10 \times 250 \mathrm{~mm}, 3 \mathrm{~mL} \cdot \mathrm{min}^{-1}$ flow rate) was used for normal-phase separations. Silica gel (Merck, Geduran ${ }^{\circledR}$ Si $600.063-0.2 \mathrm{~mm}$ ) was used for column chromatography. All solvents were either ACS or HPLC grade and were obtained from JT Baker (Phillipsburg, NJ, USA). 5-FU was purchased from Sigma-Aldrich (St. Louis, MO, USA).

\subsection{Plant Material}

The fruiting bodies of Antrodia camphorata were collected in Taoyuan, Taiwan, in the summer of 2009, and kindly provided to our laboratory by the Cosmos Biotech. Company (Longtan, Taiwan). The sample was authenticated by Tien-Wang Chiu (general manager of Cosmos Biotech. Company), and a voucher specimen (AC2009-1) was deposited at the School of Pharmacy, Taipei Medical University, Taipei, Taiwan.

\subsection{Extraction and Isolation}

A. camphorata (48 g) were cut into small pieces and extracted with $4 \mathrm{~L}$ ethanol at room temperature for seven days. After removal of the solvent under reduced pressure, the ethanolic extract residue was separated by silica gel column chromatography with $n$-hexane, ethyl acetate, and methanol. Fractions of $100 \mathrm{~mL}$ each were collected and monitored by TLC using $n$-hexane/ethyl acetate $(4: 1$ and 3:1, v/v) or $n$-hexane/acetone $(3: 1, \mathrm{v} / \mathrm{v})$ and observed at $254 \mathrm{~nm}$. Fractions with similar components were pooled into 25 portions. Silica gel column chromatography of portions 1-4 (1.5 g) comprised stepwise elution with $n$-hexane/ethyl acetate $(99: 1,98: 2$, and 95:5, v/v), and finally, with pure ethyl acetate. Subfractions 12-18 were separated by normal-phase HPLC on a semipreparative normal phase column (Phenomenex Luna silica, $5 \mu \mathrm{m}, 10 \times 250 \mathrm{~mm}$ ) at a flow rate of $3 \mathrm{~mL} \cdot \mathrm{min}^{-1}$, with a mixture of $n$-hexane/ethyl acetate $(49: 1, \mathrm{v} / \mathrm{v})$, to afford compounds $3\left(320 \mathrm{mg}, \mathrm{t}_{\mathrm{R}}=23.9 \mathrm{~min}\right)$ and $1(12 \mathrm{mg}$, $\left.\mathrm{t}_{\mathrm{R}}=26.5 \mathrm{~min}\right)$. Compound $2\left(39 \mathrm{mg}, \mathrm{t}_{\mathrm{R}}=11.9 \mathrm{~min}\right)$ was obtained from subfractions $26-28$ by HPLC 
with an isocratic mixture of $n$-hexane/acetone $(30: 1, \mathrm{v} / \mathrm{v})$, and then, with $n$-hexane/ethyl acetate/acetone $(60: 1: 1, \mathrm{v} / \mathrm{v} / \mathrm{v})$.

Antrocamphin $O$ (1): colorless amorphous powder; UV (MeOH) $\lambda_{\max }(\log \varepsilon) 213$ (4.52), 258 (3.61), 288 (3.96) $\mathrm{nm}$; IR (neat) $v_{\max } 2942,2183,1605,1469,1449,1276,1051 \mathrm{~cm}^{-1}$; ${ }^{1} \mathrm{H}$ - and ${ }^{13} \mathrm{C}-\mathrm{NMR}$ data, see Table 1; ESIMS (positive) $m / z 261[\mathrm{M}+\mathrm{H}]^{+}$; HRESIMS (positive) $m / z 261.1123[\mathrm{M}+\mathrm{H}]^{+}$(calcd. for $^{2}$ $\left.\mathrm{C}_{15} \mathrm{H}_{16} \mathrm{O}_{4} 261.1127\right)$.

Antrocamphin A (2): ESIMS (positive) $m / z 247[\mathrm{M}+\mathrm{H}]]^{+} ;{ }^{1} \mathrm{H}$ and ${ }^{13} \mathrm{C}-\mathrm{NMR}$ data, see reference [8].

4,7-Dimethoxy-5-methyl-1,3-benzodioxole (3): ESIMS (positive) $m / z 197[\mathrm{M}+\mathrm{H}]]^{+} ;{ }^{1} \mathrm{H}$ and ${ }^{13} \mathrm{C}-\mathrm{NMR}$ data, see reference [9].

\subsection{Synthesis}

Synthesis of 3,4-dihydroxy-2,5-dimethoxytoluene (5). To a solution of 2,3,4,5-tetramethoxytoluene 4 $(0.94 \mathrm{~g}, 4.43 \mathrm{mmol})$ in anhydrous dichloromethane $(12 \mathrm{~mL})$ was added $\mathrm{AlCl}_{3}(1.30 \mathrm{~g}, 9.77 \mathrm{mmol})$ under nitrogen. The mixture was heated to $40{ }^{\circ} \mathrm{C}$ for $16 \mathrm{~h}$. After cooling to room temperature, the mixture was poured into iced water $(60 \mathrm{~mL})$ and extracted with dichloromethane. The organic layer was washed with saturated $\mathrm{NaCl}$ solution, and was then purified by column chromatography (eluent: ethyl acetate/hexane $=1: 4$ to $1: 1)$ to afford pure 5 as a yellowish oil $(0.28 \mathrm{~g}$, yield: $34 \%)$. TLC $\mathrm{R}_{\mathrm{f}}: 0.28$ (EtOAc:hexane 1:1); ${ }^{1} \mathrm{H}-\mathrm{NMR}\left(\mathrm{CDCl}_{3}\right) \delta 2.22(\mathrm{~s}, 3 \mathrm{H}), 3.78(\mathrm{~s}, 3 \mathrm{H}), 3.82(\mathrm{~s}, 3 \mathrm{H}), 5.48$ (br s, 1H), 5.66 (br s, $1 \mathrm{H}), 6.24(\mathrm{~s}, 1 \mathrm{H}) ;{ }^{13} \mathrm{C}-\mathrm{NMR}\left(\mathrm{CDCl}_{3}\right) \delta 15.5,56.2,60.6,104.0,120.9,131.5,137.1,140.3,143.4$.

Synthesis of 4,7-dimethoxy-5-methyl-1,3-benzodioxole (3). To a solution of 5 (240 $\mathrm{mg}$, $1.35 \mathrm{mmol})$ dissolved in dimethyl sulfoxide $(3 \mathrm{~mL})$ were added bromochloromethane $(227 \mathrm{mg}, 1.76 \mathrm{mmol})$ and $\mathrm{Cs}_{2} \mathrm{CO}_{3}$ (442 mg, $\left.1.35 \mathrm{mmol}\right)$. The mixture was then heated to $110{ }^{\circ} \mathrm{C}$ under nitrogen for $16 \mathrm{~h}$. The mixture was cooled and then diluted by the addition of water $(15 \mathrm{~mL})$. The mixture was extracted with isopropanol $(15 \mathrm{~mL})$, and the extract was washed with saturated $\mathrm{NaCl}$ solution. A dark brown raw product $(250 \mathrm{mg}$ ) was obtained, which was purified by column chromatography (eluent: ethyl acetate/hexane $=1: 5)$, affording 3 as a colorless liquid $(85 \mathrm{mg}$, yield: $70 \%)$. TLC $\mathrm{R}_{\mathrm{f}}: 0.52$ (EtOAc:hexane 1:2); ${ }^{1} \mathrm{H}-\mathrm{NMR}\left(\mathrm{CDCl}_{3}\right) \delta 2.17(\mathrm{~s}, 3 \mathrm{H}), 3.84(\mathrm{~s}, 3 \mathrm{H}), 3.88(\mathrm{~s}, 3 \mathrm{H}), 5.93(\mathrm{~s}, 2 \mathrm{H}), 6.30$ $(\mathrm{s}, 1 \mathrm{H}) ;{ }^{13} \mathrm{C}-\mathrm{NMR}\left(\mathrm{CDCl}_{3}\right) \delta 15.8,56.8,59.8,101.3,108.8,123.5,134.6,136.5,138.6,138.8$; ESIMS (positive) $m / z: 197[\mathrm{M}+\mathrm{H}]^{+}$.

Synthesis of 5-iodo-4,7-dimethoxy-6-methyl-1,3-benzodioxole (6). To a solution of 3 (240 mg, $1.35 \mathrm{mmol}$ ) dissolved in bromochloromethane $(2 \mathrm{~mL})$ was added $N$-iodosuccinimide (217 $\mathrm{mg}$, $0.97 \mathrm{mmol})$. The reaction was heated to $37^{\circ} \mathrm{C}$ and allowed to proceed overnight. The mixture was cooled and then diluted with water $(5 \mathrm{~mL})$. The mixture was extracted with $\mathrm{CH}_{2} \mathrm{Cl}_{2}(6 \mathrm{~mL})$, then washed with $10 \% \mathrm{Na}_{2} \mathrm{~S}_{2} \mathrm{O}_{3}$ solution $(10 \mathrm{~mL})$. The product, 6 , was obtained as a light-orange oil (248 $\mathrm{mg}$, yield: $88 \%$ ). ${ }^{1} \mathrm{H}-\mathrm{NMR}\left(\mathrm{CDCl}_{3}\right) \delta 2.34\left(\mathrm{~s}, 3 \mathrm{H},-\mathrm{CH}_{3}\right), 3.87\left(\mathrm{~s}, 3 \mathrm{H},-\mathrm{OCH}_{3}\right), 3.92\left(\mathrm{~s}, 3 \mathrm{H},-\mathrm{OCH}_{3}\right), 5.96$ (s, $\left.2 \mathrm{H},-\mathrm{OCH}_{2} \mathrm{O}-\right) ;{ }^{13} \mathrm{C}-\mathrm{NMR}\left(\mathrm{CDCl}_{3}\right) \delta 21.4,60.1,60.2,87.9,101.6,127.7,136.2,137.3,138.3,139.6$. 
Synthesis of 4,7-dimethoxy-5-methyl-6-(3-methylbut-3-en-1-ynyl)benzo[d][1,3]dioxole $N, N$-Dimethylacetamide (DMA, $1.0 \mathrm{~mL}$ ) was placed in a $10 \mathrm{~mL}$ flask and heated to $60{ }^{\circ} \mathrm{C}$ for $20 \mathrm{~min}$ while purging with argon gas. To the flask was added $6(230 \mathrm{mg}, 0.71 \mathrm{mmol})$, copper iodide (130 mg, $0.71 \mathrm{mmol}), \mathrm{Pd}\left(\mathrm{PPh}_{3}\right)_{4}(130 \mathrm{mg}, 0.07 \mathrm{mmol})$, and triethylamine $(0.15 \mathrm{~mL})$, and the reaction was heated to $80{ }^{\circ} \mathrm{C}$. A solution of 2-methylbut-1-en-3-yne (192 mg, $\left.2.5 \mathrm{mmol}\right)$ was dissolved in DMA $(0.5 \mathrm{~mL})$ and added to the reaction mixture. The mixture was heated at $90{ }^{\circ} \mathrm{C}$ for $16 \mathrm{~h}$. The mixture was cooled, and then, it was filtered after adding $15 \mathrm{ml}$ of EtOAc. The filtrate was washed with $\mathrm{H}_{2} \mathrm{O}(6 \mathrm{~mL})$. A brown product was obtained after concentration in vacuo. The raw product was purified by column chromatography (eluent: ethyl acetate/hexane $=1: 6$ ) to afford 1 as a colorless liquid (30 mg, yield: 16\%). ${ }^{1} \mathrm{H}-\mathrm{NMR}\left(\mathrm{CDCl}_{3}\right) \delta 2.01\left(\mathrm{~s}, 3 \mathrm{H},-\mathrm{CH}_{3}\right), 2.27\left(\mathrm{~s}, 3 \mathrm{H}, \mathrm{Ar}-\mathrm{CH}_{3}\right), 3.87$ (s, 3H, $\left.-\mathrm{OCH}_{3}\right), 3.98(\mathrm{~s}, 3 \mathrm{H}$, $\left.-\mathrm{OCH}_{3}\right), 5.26(\mathrm{~s}, 1 \mathrm{H}), 5.37(\mathrm{~s}, 1 \mathrm{H}), 5.93\left(\mathrm{~s}, 2 \mathrm{H},-\mathrm{OCH}_{2} \mathrm{O}-\right) ;{ }^{13} \mathrm{C} \mathrm{NMR}\left(\mathrm{CDCl}_{3}\right) \delta 13.8,23.5,60.0,60.3$, $83.5,97.5,101.4,109.9,121.0,127.2,127.8,136.3,137.2,139.5,139.8$.

\subsection{In Vitro Cytotoxicity Assay}

\subsubsection{Cell Culture}

Human colon cancer cells (HCT15, HT29, DLD-1, and COLO 205) were cultured in Dulbecco's modified Eagle medium supplemented with $10 \%$ fetal bovine serum and antibiotics $(100 \mathrm{U} / \mathrm{mL}$ penicillin and $100 \mathrm{mg} / \mathrm{mL}$ streptomycin) at $37{ }^{\circ} \mathrm{C}$ in a $\mathrm{CO}_{2}$ incubator. Cells grew to $90 \%$ confluence, were harvested with trypsin/EDTA, and sub-cultured in a new tissue culture flask after removing trypsin and EDTA. The cancer cells used in this study had passage numbers of less than ten.

\subsubsection{Cytotoxicity Assay}

Colon cancer cells $\left(1 \times 10^{5}\right.$ cells $)$ were seeded into 96-well plates and cultured overnight, allowing cell attachment. This was followed by treatment with compounds $\mathbf{1}, \mathbf{2}$, and $\mathbf{3}$ for $48 \mathrm{~h}$ at various concentrations (from 0.001 to $100 \mu \mathrm{M}$ ), as indicated, and 5-FU as a positive control. At the end of the experiment, the cytotoxicities of the compounds were examined by the MTT ((3-) 4,5 -dimethylthiazol2-yl)-2,5-diphenyltetrazolium bromide) test. MTT solution $(400 \mathrm{mg} / \mathrm{mL})$ was added into the cultured wells and incubated for $1 \mathrm{~h}$. The medium was then aspirated, and the dark blue crystal product was extracted with DMSO. Colorimetric changes were read on a microtiter plate reader with a $570 \mathrm{~nm}$ filter and a reference wavelength of $430 \mathrm{~nm}$.

\subsubsection{Statistical Analysis}

All data were expressed as the mean value \pm S.E.M. Comparisons were subjected to the Student's two-tailed t test. Significance was accepted at $p<0.05$.

\section{Conclusions}

In conclusion, we have achieved the first total synthesis of the rare new natural product, antrocamphin O (1), using the Sonogashira reaction as the key step. The intermediate 3, from the fruiting bodies of $A$. camphorata, was also successfully synthesized during the process (Scheme 1). 
Whereas enynyl-benzenoids are considered the key components responsible for the anti-inflammatory activities demonstrated by these fungi, this paper offers the first report of the inhibition of COLO 205 cancer cells by such compounds too [13].

\section{Acknowledgements}

This work was supported by the National Science Council Grants NSC-97-2320-B-038-018-MY3 (WBZ) and NSC 98-2320-B-038-015-MY3 (CKL). We are grateful to S.-H. Wang for the NMR data acquisition in the Instrumentation Center of Taipei Medical University.

\section{Conflict Interest}

The authors declare no conflict of interest.

\section{References}

1. Geethangili, M.; Tzeng, Y.M. Review of Pharmacological Effects of Antrodia camphorata and Its Bioactive Compounds. Evid. Based Complement. Alternat. Med. 2011, 2011, 212641.

2. Huang, H.C.; Liaw, C.C; Yang, H.L.; Hseu, Y.C.; Kuo, H.T.; Tsai, Y.C.; Chien, S.C.; Amagaya, S.; Chen, Y.C.; Kuo, Y.H. Lanostane triterpenoids and sterols from Antrodia camphorata. Phytochemistry 2012, 84, 177-183.

3. Shi, L.S.; Chao, C.H.; Shen, D.Y.; Chan, H.H.; Chen, C.H.; Liao, Y.R.; Wu, S.J.; Leu, Y.L.; Shen, Y.C.; Kuo, Y.H.; et al. Biologically active constituents from the fruiting body of Taiwanofungus camphorates. Bioorg. Med. Chem. 2011, 19, 677-683.

4. Tsai, Z.T.; Liaw, S.L. The Use and the Effect of Ganoderma; Sang-Yun Press: Taichung, Taiwan, 1982; p. 116.

5. Lee, Y.P.; Tsai, W.C.; Ko, C.J.; Rao, Y.K.; Yang, C.R.; Chen, D.R.; Yang, M.H.; Yang, C.C.; Tzeng, Y.M. Anticancer effects of eleven triterpenoids derived from antrodia camphorate. Anticancer Res. 2012, 32, 2727-2734.

6. Liao, Y.R.; Kuo, P.C.; Huang, S.C.; Liang, J.W.; Wu, T.S. An efficient total synthesis of Benzocamphorin $\mathrm{H}$ and its anti-inflammatory activity. Tetrahedron Lett. 2012, 53, 6202-6204.

7. Lee, C.L.; Huang, C.H.; Wang, H.C.; Chuang, D.W.; Wu, M.J.; Wang, S.Y.; Hwang, T.L.; Wu, C.C.; Chen, Y.L.; Chang, F.R.; et al. First total synthesis of antrocamphin A and its analogs as anti-inflammatory and anti-platelet aggregation agents. Org. Biomol. Chem. 2011, 9, 70-73.

8. Chen, J.J.; Lin, W.J.; Liao, C.H.; Shieh, P.C. Anti-inflammatory benzenoids from Antrodia camphorate. J. Nat. Prod. 2007, 70, 989-992.

9. Chiang, H.C.; Wu, D.P.; Cherng, I.W.; Ueng, C.H. A sesquiterpene lactone, phenyl and biphenyl compounds from Antrodia cinnamomea. Phytochemistry 1995, 39, 613-616.

10. Piggott, M.J.; Wege, D. The synthesis of ventilone A. Aus. J. Chem. 2000, 53, 749-754.

11. Rudyanto, M.; Kobayashi, K.; Honda, T. Synthetic studies on natural isocoumarins and isocarbostyril derivatives having an alkyl substituent at the 3-position: Total synthesis of scoparines A and B, and ruprechstyril. Heterocycles 2009, 79, 753-764. 
12. Smith, L.R.; Mahoney, N.; Molyneux, R.J. Synthesis and structure-phytotoxicity relationships of acetylenic phenols and chromene metabolites, and their analogues, from the grapevine pathogen Eutypa lata. J. Nat. Prod. 2003, 66, 169-176.

13. Lee, C.K.; Chen, P.Y.; Lo, J.M.; Chung, W.B.; Chiu, T.W.; Yu, C.C. Compound extracted from Antrodia camphorate, medical composition containing the same and their application in producing the producing the medical formulations for preventing and treating rectal camcer. Faming Zhuanli Shenqing CN 103012358 A 20130403, 2013.

Sample Availability: Not available.

(C) 2013 by the authors; licensee MDPI, Basel, Switzerland. This article is an open access article distributed under the terms and conditions of the Creative Commons Attribution license (http://creativecommons.org/licenses/by/3.0/). 